\title{
A EXTENSÃO UNIVERSITÁRIA: CONTRIBUIÇÕES DAUNIVERSIDADE FEDERAL DE SÃO CARLOS/UFSCAR PARA AS RELAÇÕES ÉTNICO-RACIAIS
}

\author{
Danielle Souza Petto ${ }^{1}$ \\ Manoel Nelito Matheus Nascimento ${ }^{2}$
}

\begin{abstract}
Resumo
Este artigo busca apresentar a extensão universitária sobre as relações étnico-raciais na UFSCar, inicialmente abordando o desenvolvimento histórico da extensão na universidade brasileira e num segundo momento a extensão universitária da UFSCar. Percebe-se que essa relação é permeada por muitos elementos que contribuem para que o diálogo avance ou retroceda, e que é necessário compreender a universidade a partir da totalidade em que ela está inserida. A universidade tem o papel fundamental de promover o avanço do conhecimento sobre a sociedade, formular ações, dar novos significados para estigmas históricos e estreitar a relação com a comunidade externa, via o ensino, a pesquisa e a extensão. No entanto, esta relação é limitada pela esfera política, dado que é por meio dela que é possível implementar as políticas públicas. Por isso, a universidade deve estar atenta às suas ações que podem contribuir para o distanciamento e o não pertencimento da comunidade externa. A extensão universitária pode servir como um mecanismo para reforçar a desigualdade social se as ações que contribuem para a transformação acabarem ficando restritas apenas àqueles professores que já tinham um comprometimento social. Portanto, é preciso haver uma reflexão constante sobre essa relação com a comunidade para que a universidade assuma o seu compromisso social.
\end{abstract}

Palavras-chave: Extensão universitária. UFSCar. Relações étnico-raciais.

\section{THE UNIVERSITY EXTENSION: CONTRIBUTIONS FROM THE UNIVERSIDADE FEDERAL DE SÃO CARLOS/UFSCAR FOR ETHNIC-RACIAL RELATIONS}

\begin{abstract}
This article presents the university extension on the ethnic-racial relations in the UFSCar, initially approaching the historical development of the extension in the Brazilian university and in a second moment the university extension of the UFSCar. It is perceived that this relationship is permeated by many elements that contribute to the dialogue to advance or retreat, and that it is necessary to understand the university from the totality in which it is inserted. The university has a fundamental role to promote the advancement of knowledge about society, formulate actions, give new meanings to historical stigmas and strengthen the relationship with the external community through teaching, research and extension. However, this relationship is limited by the political sphere, since it is through it that it is possible to implement public policies. Therefore, the university must be attentive to its actions that can contribute to the detachment and non-belonging of the external community. University extension can serve as a mechanism to reinforce social inequality if
\end{abstract}


the actions that contribute to the transformation end up being restricted only to those teachers who already had a social commitment. Therefore, it is necessary to have constant reflection on this relationship with the community so that the university assumes its social commitment.

Keywords: University extension. UFSCar. Ethnic-racial relations.

\section{LA EXTENSIÓN UNIVERSITARIA: CONTRIBUCIONES DE LA UNIVERSIDADE FEDERAL DE SÃO CARLOS/ UFSCAR PARA LAS RELACIONES ÉTNICO-RACIALES}

\section{Resumen}

Este artículo busca presentar la extensión universitaria sobre las relaciones étnico-raciales en la UFSCar, inicialmente abordando el desarrollo histórico de la extensión en la universidad brasileña y en un segundo momento la extensión universitaria de la UFSCar. Se percibe que esa relación está impregnada por muchos elementos que contribuyen para que el diálogo avance o retroceda, y que es necesario comprender la universidad a partir de la totalidad en que está inserta. La universidad tiene el papel fundamental promover el avance del conocimiento sobre la sociedad, formular acciones, dar nuevos significados para estigmas históricos y estrechar la relación con la comunidad externa, a través de la enseñanza, la investigación y la extensión. Sin embargo, esta relación está limitada por la esfera política, dado que es por medio de ella que es posible implementar las políticas públicas. Por eso, la universidad debe estar atenta a sus acciones que pueden contribuir al distanciamiento y al no pertenencia de la comunidad externa. La extensión universitaria puede servir como un mecanismo para reforzar la desigualdad social si las acciones que contribuyen a la transformación acaban quedando restringidas sólo a aquellos profesores que ya tenían un compromiso social. Por lo tanto, hay que haber una reflexión constante sobre esa relación con la comunidad para que la universidad asuma su compromiso social.

Palabras clave: Extensión Universitaria. UFSCar. Relaciones étnico-raciales.

\section{INTRODUÇÃO}

Este artigo tem a principal finalidade de discutir a extensão universitária sobre as relações étnico-raciais na UFSCar, apresentando inicialmente o desenvolvimento histórico da universidade na sociedade brasileira desde a perspectiva de seu surgimento tardio, para em seguida abordar a extensão universitária com um desenvolvimento breve de sua história, a função da extensão na universidade, como uma maneira de aproximação com a sociedade e por fim descrever as ações de extensão universitária na UFSCar tendo como foco a temática racial. 
A criação da universidade e as suas funções de ensino, pesquisa e extensão estão atreladas diretamente ao contexto social e aos interesses, sobretudo, da classe dominante em relação às funções que a instituição vai exercer na sociedade. Portanto, ao mesmo tempo em que recebe influências também é influenciada pela sociedade. Buffa e Canales (2007) apresentam um debate acerca da função da universidade, problematizando a questão de formar profissionais para o mercado de trabalho, ou sujeitos que buscam a transformação social para aqueles que não possuem os mesmos privilégios.

Teixeira (1997) afirma que a história dos países e de sua cultura é a história de suas universidades e que no decorrer dos anos a universidade vai assumindo funções que se transformam a partir do contexto em que se insere, ora influenciando, ora sendo influenciada a partir das demandas colocadas pelo sistema. A problemática da extensão universitária não está desvinculada das outras funções como afirma Saviani (1981) que quanto mais o ensino e a pesquisa se articulam com a sociedade, mais a extensão pode ocorrer.

Estudos de Semeraro (1999) demonstram que a sociedade civil ${ }^{3}$ pode tornar-se um espaço privilegiado de atuação da classe trabalhadora para se articular e confrontar seus projetos éticos e políticos com a classe dominante e dessa maneira disputar e confrontar suas ideias e ações. A universidade é um dos espaços em que essa disputa pode acontecer.

A universidade, historicamente, age privilegiando grupos economicamente favorecidos, inclusive por meio da extensão universitária. Por isso é necessário que a universidade se fortaleça, não no sentido de suprir a ausência do Estado, mas sim estar vinculada aos interesses das camadas populares e desenvolver políticas de extensão que tenham mais autonomia em relação ao governo que por sua vez se compromete com grupos dominantes. (SANCHEZ, 1996).

É necessário que a universidade incentive e divulgue a produção de conhecimento científico e cultural para a classe trabalhadora. (SANCHEZ, 1996). Somente desta maneira é possível superar as práticas muitas vezes assistencialistas e esporádicas, sendo fundamental o fortalecimento de programas que dialoguem com a classe trabalhadora e se contraponham aos programas oficiais que muitas vezes atendem apenas ao interesse do capital.

\section{BREVE HISTÓRICO DA UNIVERSIDADE BRASILEIRA}

O Brasil foi constituindo o seu ensino superior a partir de modelos exteriores, e sob o controle e permissão da metrópole portuguesa. Pode-se afirmar que a relação e o compromisso social do ensino superior no Brasil foram até então com as elites dominantes, com o objetivo claro de formar os quadros dirigentes do país. Não houve um ensino 
superior constituído a partir do contexto nacional e do interesse do povo, a partir de experiências próprias. (TEIXEIRA, 1989).

O período da primeira República, de 1889 até 1930, foi marcado pelo surgimento de diversos estabelecimentos isolados de ensino superior, que dariam origem às universidades, posteriormente. Teixeira (1989) atribuiu às faculdades isoladas do país um caráter de corporação de estudantes e professores e chamou-as ainda de "torre de marfim" que visavam à cultura universal e estavam distantes do contexto atual. No entanto, Michelotto (1999) e Fagundes (1986) fazem uma crítica em relação a essa posição de Teixeira (1989), uma vez que acreditam que a universidade não pode ser compreendida como "torre de marfim" pois ela está constantemente relacionada a interesses de diferentes grupos dominantes.

No período de 1930 a 1940, o Brasil viveu um momento intenso de debate acerca da relação entre educação e trabalho, sobretudo sobre a questão do ensino superior e a necessidade de formar quadros técnicos para modernizar o país. Esse período foi importante pois o modelo institucional de universidade foi iniciado e foi se consolidando. Uma das ações do ministro Francisco de Campos que influenciou o ensino superior foi a criação do Estatuto das Universidades Brasileiras, a partir do decreto $\mathrm{n}^{\circ}$ 19.851, em 11 de abril de 1931. Nesse decreto ficou estabelecido que as universidades seriam criadas aproveitando as estruturas organizacionais que já estavam sendo utilizadas nas escolas isoladas de ensino superior. Segundo Cunha (1989) este decreto tinha o objetivo de manter as universidades sob o controle do governo central, bem como modernizar o ensino superior.

Buscando consolidar o projeto de modernização das universidades brasileiras, em 1934, foi criada a Universidade de São Paulo, que se organizou a partir de faculdades isoladas. Segundo Fávero (2000), essa universidade surgiu para validar a importância do poder político do Estado de São Paulo em relação ao governo federal. "O sistema educacional, sobretudo o ensino superior, vivia este contexto de transição do capitalismo e até 1945 o país possuía 5 universidades e 293 estabelecimentos isolados." (CUNHA, 1989, p. 14).

O início da década de 1950 foi marcado pela aceleração do desenvolvimento do país com o aumento da industrialização e da urbanização, e esse processo refletiu na criação de universidades, pois, de acordo com Cunha (1989), subiram de 5, em 1945, para 47 em 1964, e o número de estabelecimentos isolados aumentou de 293 para 564. Esse aumento foi fruto do resultado do deslocamento dos canais de ascensão, que por sua vez são resultantes do processo de monopolização. Somado a este processo, outros fatores foram importantes para o aumento do número de universidade, tais como a transferência da população do campo para a cidade e o aumento da escolarização das mulheres. (CUNHA, 1989). 
Segundo Fávero (2000), a República Populista marcou um período muito fecundo uma vez que houve diferentes propostas para o ensino superior a partir da análise da realidade brasileira. Muitos movimentos exigiam a modernização do ensino superior, e o processo foi coordenado pelo Estado, "[...] mas com respaldo da sociedade civil, da SBPC e da $\mathrm{UNE}^{4}$, que, em especial, teve um papel de destaque nas reivindicações para o ensino superior." (CUNHA, 1989, p. 255).

Sanfelice (2008) reflete que o papel da União Nacional dos Estudantes foi fundamental. Havia uma crítica ao caráter da universidade no Brasil, pois consideravam-na um local de privilégio econômico para poucos jovens, tinha falha na missão cultural, social e profissional da universidade. Além disso, pensaram em estratégias e diretrizes para que a universidade se abrisse e se democratizassem para todos aqueles que estavam fora, sem que isso implicasse no assistencialismo, os estudantes acreditavam que era necessário despertar a consciência da população.

O início da modernização do ensino superior, segundo Cunha (1989), deu-se com a criação do Instituto Tecnológico de Aeronáutica/ITA em 1947, e atingiu seu auge com a criação da Universidade de Brasília, em 1961. A UnB foi a primeira instituição que não nasceu da integração de escolas isoladas e de faculdades, tendo sido criada e definida a partir de institutos, centros, faculdades e outras universidades.

Ao chegar o período militar a problemática da educação continua sendo pauta, uma vez que esta é utilizada de maneira estratégica e ideológica. Era necessário atender as diferentes demandas da sociedade, tais como o mercado de trabalho, a ascensão da classe média, assim como desenvolver tecnologicamente o país. Foi neste período em que houve o aumento da industrialização e da concentração de capital.

A reforma universitária deveria vir pautada em dois princípios: o desenvolvimento da industrialização e a reforma da sociedade. No entanto, os militares enfrentavam o problema de reformar e modernizar a universidade e ao mesmo tempo acalmar os movimentos sociais que emergiram do período anterior. (MICHELOTTO, 1999).

A reforma de 1968, segundo Sanchez (1996), pautou-se pelo modelo norteamericano, que envolve a origem dos departamentos, a organização racional do trabalho, e a produção e disseminação do conhecimento. Um exemplo dessa importação foi o acordo direto com os Estados Unidos: o MEC/USAID ${ }^{5}$.

A perspectiva que predominou na reforma foi a tecnocrata, inspirada no modelo estadunidense. Buffa e Canales (2007) afirmam que a lei 5.540/68 eliminou o sistema de cátedra, abriu espaço para a contratação de professores em regime de tempo integral, e impôs o tripé "ensino, pesquisa e extensão". Em relação à pesquisa houve o incentivo para se realizar, mais qualificação, institucionalizou-se a pós-graduação (com aumento de teses e dissertações no país). Estas transformações conseguiram a simpatia e a cooptação da 
Artigo

doi: $10.20396 /$ rho.v18i4.8653367

comunidade acadêmica, pois os seus membros estavam interessados na melhoria de suas condições de trabalho. (MENEGHEL, 2001, p. 138).

De uma maneira geral as funções de ensino, pesquisa e extensão não são relevantes socialmente, e muitas vezes não são propostas temáticas que contribuem para as melhorias na sociedade. Tampouco há preocupação com os problemas e demandas da mesma, o que acaba acarretando o distanciamento entre universidade e sociedade, fazendo com que a instituição se aproxime cada vez mais da iniciativa privada, já que essa está preocupada em manter um modelo e padrão internacional atendendo aos interesses e demandas do capital. Saviani (1981) aponta que há uma responsabilidade da universidade devolver aquilo que ela própria recebeu; a universidade só existe porque a sociedade a sustenta, ou seja, a sociedade como um todo cria o privilégio para alguns.

Portanto, a lei 5540/68 foi fruto de um contexto em que o país buscava a modernização para inserir-se no capitalismo, e para isso era necessário democratizar e ampliar o acesso ao ensino superior. Esse por sua vez foi visto como um instrumento fundamental para a modernização do país em busca do ensino de ciência e tecnologia. A lei atendeu às demandas da classe dominante, bem como aos interesses de países como os Estados Unidos.

A modernização econômica e o processo de "milagre econômico" não geraram o desenvolvimento do país, a sociedade em geral não ganhou os benefícios da modernização. Segundo Meneghel (2001), quando ocorreu a crise do petróleo em 1979 veio à tona a dívida externa brasileira, com elevação da taxa de juros e encerrando o período de expansão. O novo momento que se inaugurava, o qual envolvia a crise econômica, a pressão da sociedade civil e a abertura política, possibilitou a elaboração da Constituição de 1988.

No âmbito da educação o processo histórico que marcou a elaboração da LDB de 1996 inicia-se no período denominado de transição política entre a ditadura, presente no país por duas décadas, até a eleição de Fernando Collor de Mello. A universidade e sua nova reformulação foram inseridas nesse contexto, e, segundo Meneghel (2001), o fracasso do modelo de indissociabilidade entre ensino e pesquisa que havia sido proposta pela reforma de 68 somado à "nova crise" da universidade foi acentuado com os cortes de recursos e a críticas de diferentes segmentos da sociedade. Portanto, a alteração de um regime ditatorial para o democrático alterou o papel da universidade também.

No entanto, com a crise do capitalismo e a hegemonia do modelo de Estado neoliberal, o Estado passou a investir minimamente na economia dos países. As políticas neoliberais compreendem que o principal mecanismo de regulação social passou a ser o mercado. Desse modo, adotaram-se na área social características do mercado, tais como: competitividade, apelo ao mérito individual, corte nos gastos sociais, entre outras. 
No Brasil, o período que perpassa os governos Collor de Mello (1990-1991), Itamar Franco (1992-1994) e o octênio do Fernando Henrique Cardoso, foi denominado de período de modernização conservadora. (SGUISSARDI, 2006). Essa modernização foi intensificada durante o governo do Fernando Henrique Cardoso no qual ocorreram mudanças na esfera pública e privada e a educação superior também foi atingida por essas transformações. Esse período é marcado pela consolidação das ideias neoliberais no Brasil.

Identificam-se nesse período os investimentos do Banco Mundial em programas de projetos de educação, seguindo essa lógica financeira do mercado neoliberal, por meio de concessão de empréstimos que lhe dava lucros, assim como lhe dava aos seus interesses.

A educação tinha um papel central nessa reforma do Estado e os caminhos para a reforma e modernização da universidade já estavam sendo traçados. Os objetivos eram avaliação, autonomia e melhoria, com o mínimo de recursos e o máximo de eficiência. Esse contexto culminou na Lei de Diretrizes e Bases de Educação Nacional de 1996, em que houve ampla discussão e a elaboração de dois projetos, um que representava a sociedade civil, e outro, elaborado por Darcy Ribeiro. O projeto aprovado foi o segundo, representando os interesses do governo, que foi sendo adaptado a partir das políticas e interesses que o poder executivo elaborava. (CUNHA, 2003). O resultado foi uma LDB que não possui nem todas as diretrizes, nem as bases para a educação nacional, visto que há conteúdos que estão ausentes, como aponta Cunha (2003) sobre o Conselho Nacional de Educação ou a avaliação universitária.

Embora a lei estabeleça as diretrizes e bases para a educação superior, não houve uma legislação complementar que normatizasse algumas medidas. A solução encontrada pelo MEC foi o estabelecimento de decretos e portarias. (MENEGHEL, 2001). Essa questão reforça o que Cunha (2003) chamou de "minimalista", uma vez que na lei não havia diretrizes suficientes, nem bases para a educação superior nacional. Por isso precisou-se de "legislações complementares" à LDB/96, o que Meneghel (2001) aponta como um fator que deixa dúvidas sobre a legitimidade do MEC em relação às determinações dos rumos das políticas para o setor.

As transformações que ocorreram nas universidades durante esse período servem para atender às demandas do Estado neoliberal. A justificativa é de melhoria de qualidade, com economia de recursos, não privilegiando os aspectos sociais, mas sim as questões econômicas.

\section{A EXTENSÃO UNIVERSITÁRIA NO BRASIL}

A questão da extensão apareceu anteriormente na Reforma Francisco Campos de 1931 e na LDB instituída em 1961. No entanto, foi com a reforma de 1968 que se deu a sua configuração e sua consolidação com o Projeto Centros Rurais Universitários de 
Treinamento e Ação Universitária (CRUTAC) e o Projeto Rondon. Michelotto (1999) aponta que essa foi a maneira de responsabilizar a universidade e que a instituição tem o dever de alcançar o avanço cultural e o desenvolvimento da sociedade.

No Estatuto das Universidades Brasileiras, decreto $\mathrm{n}^{\circ} 19.851$ de 11 de abril de 1931, a concepção de extensão voltada para o desenvolvimento cultural da população que não estava tendo acesso aos bens produzidos é definida da seguinte forma:

\begin{abstract}
A extensão universitária se destina a dilatar os benefícios da atmosfera universitária àqueles que não se encontravam diretamente associados a vida da universidade, dando assim maior amplitude e mais longa ressonância; às atividades universitárias que concorrerão de modo eficaz para elevar o nível cultural geral do povo. (VILLAR, 2011, p. 42).
\end{abstract}

A Lei de Diretrizes e Bases da Educação Nacional no 4.024 de 1961 também definiu a concepção de extensão que vai ser anterior à Reforma Universitária. Segundo Villar (2011), a lei definiu no seu Art. 29 que a extensão ocorreria por meio de cursos de especialização, aperfeiçoamento, e extensão ou quaisquer outros, a juízo do respectivo instituto de ensino, abertos a candidatos com preparo e os requisitos que vierem a ser exigidos. No entanto atende àqueles que já estão inseridos no meio universitário apesar de no discurso aparecer aberto à comunidade externa também.

Para Fagundes (1986, p. 72) a extensão começou a ser pensada nesse período para reparar a ausência de benefícios que a universidade deveria oferecer à grande parte da população brasileira. Fagundes (1986) atribuiu a ideia de extensão ao termo "compromisso social" cujo objetivo era de recuperar a dimensão social da universidade e integrar aqueles segmentos que se encontram a margem, salvar valores culturais, e redistribuir renda.

Fagundes (1986) ressalta que a extensão foi utilizada como um apelo ao compromisso social da universidade, e que teve sua primeira referência no Decreto lei $\mathrm{n}^{\circ}$ 252 de 28 de fevereiro de 1967 no qual se dizia que a universidade tem como missão educativa o papel de estender aquilo que produz e transmiti-lo à população. Mais tarde se transforma no Art. 20 da Lei 5540/68 a lei da Reforma Universitária que implementa ainda no Art. 40 a questão de os docentes participarem de atividades que possibilitem a integração com a comunidade.

O MEC, após a implementação da lei da Reforma fez uma avaliação, e, no que diz respeito à extensão, as atividades mais desenvolvidas foram: cursos, seminários, prestação de serviços à comunidade e ação comunitária em campi avançado. Desde aquele período, o papel da extensão é polêmico e indefinido, pois o próprio MEC indica a questão das dificuldades de definir a função da extensão, pois essa possui dificuldades para se consolidar como uma atividade além de "[...] não ser esta propriamente uma terceira função da universidade, que participe da mesma natureza e do mesmo nível conceitual do ensino e da pesquisa." (FAGUNDES, 1986, p. 74). 
De acordo com Fagundes (1986), além dessas questões há um debate sobre a diferença entre o objetivo declarado e o objetivo real. Aparentemente a universidade deve estender as atividades de ensino e pesquisa, servindo à comunidade carente, trazendo mais informações, assim realimentando as funções de ensino. No entanto, o que não é declarado ideologicamente é o mecanismo político de ajustamento e acomodação social.

O debate acerca da apropriação desigual dos bens culturais não foi feito ao longo da história do país e Fagundes (1986) compreende que a instituição é um reflexo da sociedade desigual. No entanto, o Estado, amparado pela classe dominante, espera que a universidade corrija as questões da sociedade que foi gerada por um sistema que tem em sua essência a desigualdade e a apropriação particular de bens produzidos. A reflexão da questão da apropriação é percebida por Fagundes (1986) da seguinte forma:

\footnotetext{
Enquanto não for abandonada essa maneira de se pensar a realidade, não se pode nem falar, nem esperar que a universidade venha a ser um agente transformador social, uma vez que seu compromisso social, mediatizado pelas atividades extensionistas, é antes um compromisso com a manutenção das estruturas do que com a transformação das mesmas. (FAGUNDES, 1986, p. 80).
}

Portanto, a extensão no período da ditadura civil militar teve um papel fundamental, o de silenciar os jovens que pediam a reforma universitária e que queriam prestar assistência à população mais carente. (MICHELOTTO, 1999). Ou seja, as medidas tomadas pelo governo contribuíram para que as reais transformações na estrutura social do capitalismo não acontecessem. A postura do governo com as ações "sociais" levou as pessoas a acreditarem que ele contribuía para o desenvolvimento do indivíduo e da sociedade, quando na verdade, estava preocupado com a "ordem e o progresso". Os programas que marcaram esse período e a consolidação da extensão foram o Centro Rural de Treinamento e Ação Comunitária (CRUTAC) e o Projeto Rondon.

O CRUTAC iniciou suas atividades na Universidade Federal do Rio Grande do Norte, e tinha como objetivo o treinamento mais a prestação de serviços. Os estudantes eram submetidos a estágios rurais que envolviam diferentes áreas, tais como saúde, educação, engenharia. A experiência dessa universidade ampliou-se e foi percebida e implementada por diferentes universidades.

No ano de 1969, com o Decreto-Lei n ${ }^{\circ} 916$ de 7 de setembro, criou-se a Comissão Incentivadora dos Centros Rurais e Urbanos de Treinamento e Ação Comunitária, o CINCRUTAC, o qual tinha como objetivo ajustar as ações governamentais às necessidades das populações do interior do país. As universidades deveriam realizar cursos específicos, atender à população em situação de abandono e pobreza.

O governo, por meio do CRUTAC, justificava suas ações utilizando o discurso de contribuir com as questões sociais, mas a sua verdadeira preocupação era com o desenvolvimento e progresso do país e com a segurança, estabelecendo a ordem e a 
unidade. Fagundes (1986) aponta a questão da imposição de temas que vêm da universidade, em que as pessoas não participam e a comunidade não tem a palavra: são temas colocados e problematizados apenas pela própria universidade. Esse programa deveria formar os estudantes para atender e assistir às comunidades rurais que estavam em situação de abandono ou pobreza. A população era culpabilizada pela situação de atraso, e a universidade deveria ter como "missão" a salvação dessa população.

Outro projeto que pode ser destacado no período da ditadura civil militar é o Projeto Rondon. Esse projeto tinha como lema "integrar para não entregar" e buscava a participação de jovens universitários nas ações em comunidades. Existia a ideia de que a juventude brasileira precisava conhecer a realidade do país em que estava inserido (SAVIANI, 1981; FAGUNDES, 1986). Saviani (1981) questiona a execução desse projeto na medida em que estudantes eram recrutados, mas não participavam de maneira ativa e reflexiva. Além disso, quando retornavam à universidade, traziam questões desconhecidas à comunidade acadêmica. A primeira experiência, por exemplo, aconteceu em 1967, quando um grupo de 30 estudantes e um professor permaneceram 28 dias em Rondônia onde desenvolveram atividades de saúde e educação, voltando entusiasmados de suas experiências. (FAGUNDES, 1986, p. 87).

A experiência desses jovens foi amplamente divulgada e em 23 de junho de 1968 estabeleceu-se o Decreto $\mathrm{n}^{\mathrm{o}} 62.927$ que institui o Projeto RONDON, que vinha em consonância aos interesses do governo, bem como ao momento político, econômico, social e cultural do país, e dependia da integração de diversas áreas. Fagundes (1986) destaca a diferença entre o papel da juventude nos anos 1960 e no período militar:

[...] existe uma diferença fundamental entre a participação estudantil na década de 60 e as formas que ora são propostas. Se antes os estudantes estavam na vanguarda e queriam influir no encaminhamento dos problemas dos diferentes setores da vida nacional, agora lhes é reservado um papel caudatário. São vistos como um potencial de mão-de-obra, cuja interiorização pode contribuir para integrar as comunidades interioranas e as regiões distantes e carentes, ao projeto de desenvolvimento nacional. (FAGUNDES, 1986, p. 89).

O Projeto Rondon mantinha o apoio (a partir da manutenção e transporte dos estagiários) para que a universidade pudesse realizar suas atividades extensionistas. Esse projeto tinha como objetivo a integração das regiões distantes e carentes, com o plano de desenvolvimento do país, além de transformar a mentalidade da juventude para que entrasse em acordo com o projeto de governo. (FAGUNDES, 1986).

Saviani (1981) acredita que a extensão não deveria e não está desvinculada do ensino e da pesquisa. Para ele, a extensão tem mais chance de se realizar quando os dois ocorrem simultaneamente. A extensão era considerada naquele contexto como um mecanismo através do qual distorções sociais, de origem estruturais, seriam corrigidas. 
Como exemplo, Saviani (1981) cita o próprio projeto Rondon, em que os universitários dos centros metropolitanos e das cidades iam para as regiões menos desenvolvidas, pelo menos em certos períodos. A visão que iria predominar seria a assistencialista, na qual aqueles que têm (cultura, saberes, conhecimento) precisam prestar assistência àqueles que não têm. Saviani (1981) acredita que a questão não pode ser compreendida no âmbito da caridade, quem presta favor são aqueles que pagam os impostos, a relação é muito mais ampla, é uma questão de privilegiados e não privilegiados.

Saviani (1981) critica a própria palavra extensão - estender àqueles que não têm visto que não se considera o inverso. Uma vez que a comunidade também constrói os seus saberes no cotidiano, é fundamental considerar a relação inversa. É a sociedade que deve colocar os problemas; é o contato com os problemas efetivos da sociedade que vai permitir à universidade transformar os objetos de sua pesquisa em algo relevante para a sociedade $\mathrm{e}$ adequar o ensino às suas necessidades.

No entanto, Saviani (1981) também aponta que, apesar das ressalvas, a possibilidade de estar em contato com a realidade do país pode expor os seus problemas sociais e econômicos e isso poderia trazer consequências contrárias aos interesses do capital. O autor compreende que, na medida em que os estudantes têm contato com a realidade complexa dessa população, eles podem querer transformá-la. Pode acontecer também de os estudantes começarem a observar as questões estruturais, como desigualdade, pobreza, atraso, enquanto circunstâncias geográficas, por exemplo, ou acabem culpabilizando os próprios indivíduos por suas condições. (FAGUNDES, 1986).

Fagundes (1986) ressalta que, geralmente, há um "pensamento elitista" e um sentimento populista, pois de um lado há os detentores de saberes que "representam" os interesses do governo para o desenvolvimento, e de outro lado estão os ignorantes, aqueles que necessitam de ajuda. Esses são considerados como incapazes de solucionar seus próprios problemas, e para isso precisam de indivíduos que possam contribuir na sua resolução.

Os anos 1990 foram marcados pela redemocratização e ascensão dos movimentos sociais, mas também pela submissão do Estado à lógica neoliberal. Dentro desse contexto, a extensão segundo Sousa (2000) passa de um momento em que era considerada assistencialista - no qual predominava a disseminação do conhecimento e da cultura daqueles que detinham, para aqueles que não detinham - para um momento de discurso com o compromisso social da universidade, fruto das demandas sociais.

A extensão passa a ser compreendida nesse período como a "articuladora" do ensino e da pesquisa com a sociedade. (SOUSA, 2000). Estava em debate a questão do compromisso social da universidade no qual se compreendia que a universidade estava "isolada" da sociedade e das demandas sociais. A abertura política da universidade 
possibilitou a eleição de reitores, que por sua vez tinham o apoio dos docentes. Esse período foi marcado pela criação de fóruns, e entre eles o da extensão.

As discussões que antecederam a questão da democratização da universidade, de sua reivindicação em torno da função social e pela questão da indissociabilidade entre ensino, pesquisa e extensão, representariam a concepção que o grupo iria elaborar para a extensão. Nesse período, as atividades de extensão começam a ter reconhecimento legal e conforme aponta Leher (2015), após muitas ressignificações, a extensão foi consagrada na Constituição Federal de 1988, por meio da indissociabilidade entre ensino, pesquisa e extensão. A criação do Fórum Nacional de Pró-Reitores de Extensão das Universidades Públicas Brasileiras (FORPROEX), em novembro de 1987, é um marco importante para a extensão acadêmica.

Questões como: conceituação, institucionalização e financiamento da extensão passaram a ser discutidas entre o MEC e representantes das Instituições de Ensino Superior e a sociedade civil. (SOUSA, 2000). Segundo Sousa (2000), não havia uma definição precisa do que era a extensão, e as atividades desenvolvidas eram distantes do ensino e da pesquisa. Para a autora:

Esta falta de clareza conceitual acabava por provocar mais depreciação do status da Extensão Universitária. Afinal, não se identificava o que poderia ser prática extensionista ou não e, muitas vezes a confusão com o ensino e a pesquisa tornava mais difícil ainda essa identificação. Identificar os limites da pesquisa é possível, a confusão começa a surgir de fato a partir do ensino e se acentua quando se passa a considerar a Extensão no mesmo contexto. Os contornos tornam-se nebulosos e o desenho, irreconhecível. Tentar colocá-los como atividades independentes torna essa tarefa um esforço inútil, pois se descobre que ensino, pesquisa e extensão são atividades que se mesclam e umas às outras (SOUSA, 2000, p. 100).

Para Saviani (1981), a imposição do tripé, "ensino, pesquisa e extensão" pode ser um problema, uma vez que cada função tem sua especificidade. Há que se preocupar em não obter o objetivo ou hipertrofiar as funções, dado que o problema da pesquisa poderá se sobrepor ao ensino e o professor ao oferecer um curso se limita a "ensinar" o que se está pesquisando, mas se a função ensino se sobrepor à pesquisa poderia acarretar um ensino arcaico e atrasado, uma vez que o professor não irá atualizar e fazer reflexões diante de "novos" conhecimentos pesquisados.

O ensino é a atividade reservada para a formação profissional e transmissão de saber. A pesquisa é responsável pela produção de novos conhecimentos. A função da extensão diz respeito aos saberes acumulados, bem como à socialização dos mesmos para não ficarem restritos apenas àqueles que passaram no vestibular, podendo contribuir para elevar o nível cultural geral da sociedade.

Em consonância com as ideias de Saviani (1981), Fagundes (1986) questiona a ideia de indissociabilidade proposta pela reforma de 1968. Para o autor, acrescentar à 
universidade mais uma função não a fará necessariamente mais comprometida socialmente. O autor observa a dificuldade em compreender a extensão enquanto função, uma vez que ela seria a responsável por suprir as necessidades sociais que deveriam ser de responsabilidade do Estado.

A questão da indissociabilidade vai tornar-se hegemônica ao longo do tempo no país. Foi no I Encontro Nacional de Pró-Reitores de Extensão das Universidades Públicas Brasileiras que se definiu a extensão universitária como sendo um “[...] processo educativo, cultural e científico que deve articular o ensino e a pesquisa de maneira indissociável e possibilita a transformação da relação entre universidade e sociedade." (FORPROEX, 1987). Ou seja, a concepção de indissociabilidade prevaleceu na definição. Segundo Sousa (2000), foi nesse encontro que diferentes docentes começaram a reconhecer-se enquanto Pró-Reitores de Extensão.

Portanto, os docentes no Fórum demonstram a preocupação em colocar a extensão no mesmo patamar que as outras funções. (SOUSA, 2000). Para o Fórum, a extensão seria o "instrumento" responsável para articular o que se produz e ensina na universidade com a sociedade. Dessa forma, a instituição cumpriria o seu compromisso social. Conforme os encontros foram acontecendo, a questão da concepção da extensão foi se ampliando, e, no terceiro encontro, foi discutida a questão da interdisciplinaridade. (SOUSA, 2000).

A prestação de serviços também foi discutida nos Fóruns. Essa prestação, para o fórum, deve acontecer de maneira comprometida com a realidade social e a partir das demandas da sociedade. (SOUSA, 2000). O que predomina nessas discussões é a questão da extensão como via de articulação entre universidade e sociedade, difundindo os conhecimentos produzidos com as pessoas que não tem acesso a eles. Para Saviani (1981), se o ensino e a pesquisa cumprissem esse papel e estivessem comprometidos de fato com a sociedade que não tem esse acesso, a extensão aconteceria de forma "natural".

No Fórum de 1994, analisado por Sousa (2000), voltou-se a discutir a questão da extensão enquanto prestação de serviços e a possibilidade de a universidade adquirir recursos extra-orçamentários por meio dela. Essa questão, segundo Sousa (2000), é bastante debatida por conta de a universidade visar à produção e o lucro, agindo como uma empresa, e, embora esta atividade acadêmico-empresarial seja bastante questionada por intelectuais, que não haja reações para que estas atividades sejam impedidas. A extensão pode ser compreendida enquanto maneira de cooptar recursos da iniciativa privada e pode ser utilizada pelo Estado como justificativa de isentar-se de sua responsabilidade com o social. Conforme discutido anteriormente, o contexto político-econômico foi propício para isso, e a extensão pôde servir como meio de privatização do ensino superior público.

Sendo assim, a concepção do Fórum de Extensão Universitária, ao compreendê-la enquanto instrumento articulador entre sociedade e universidade, possibilita um espaço para a entrada da iniciativa privada. Essa questão deve ser combatida, uma vez que a 
Artigo

doi: $10.20396 /$ rho.v18i4.8653367

universidade ao fazer isso não estará comprometendo-se com aqueles que por meio de impostos pagam para que se mantenha.

Uma segunda questão discutida pelo Fórum diz respeito à institucionalização. $\mathrm{O}$ objetivo foi buscar a igualdade de funções, uma vez que dentre as funções atribuídas à universidade a extensão é a menos valorizada. Sua institucionalização pode possibilitar o estabelecimento enquanto função e para que sua prática seja efetivada, até como uma forma de garantir que a sociedade saiba o que a universidade está produzindo. (SOUSA, 2000).

Após as questões de conceituação e institucionalização da função é que se pode começar a discutir o financiamento. (SOUSA, 2000). Para os integrantes do Fórum, o financiamento da extensão deve privilegiar programas que integrem a comunidade acadêmica e a sociedade, contribuindo com o avanço dos Estados e das demandas dos Movimentos Sociais. Para saber a sua efetivação, os programas de Extensão passariam por uma avaliação. Sousa (2000) aponta que há uma indefinição sobre a formulação do conceito e a função da extensão para as próprias instituições e que isso contribui para que a prática não se relacione com o discurso.

No que diz respeito às legislações, a questão da extensão aparece na Constituição Federal de 1988 e na LDB/96, no Plano Nacional de Educação. A Constituição de 1988 irá conceitua no Artigo 207 "[...] indissociabilidade entre ensino, pesquisa e extensão" (BRASIL, 1988), bem como estabelecer o caráter financeiro da extensão no Artigo 213, $\S 2^{\circ}$ " $[\ldots .$.$] as atividades universitárias de pesquisa e extensão poderão receber apoio$ financeiro do poder público." (BRASIL, 1988). Ao estabelecer a indissociabilidade dessas três instâncias, a Constituição afirma que as três precisam coexistir juntas e que as instâncias sozinhas não são socialmente desejáveis. (ZILLER et al., 2010).

Avanços na regulamentação e na legislação aconteceram no âmbito da extensão universitária sob influência da FORPROEX, como a criação do Programa de Fomento à Extensão Universitária (PROEXTE) de 1993, que visa contribuir com o financiamento da extensão. A extensão universitária apareceu na Lei de Diretrizes e Bases da Educação Nacional (LDB), lei no 9.394/1996, que estabeleceu a extensão universitária como uma das finalidades da universidade, e instituiu a possibilidade de apoio financeiro do poder público inclusive mediante bolsas de estudo.

Segundo Villar (2011), nos anos 2000 começou a ser discutida a questão da indissociabilidade entre "vida acadêmica" e "relevância social". Para a autora, isso possibilita a superação da visão da extensão enquanto função isolada das outras, bem como atividade voltada para os estudantes se formarem enquanto cidadãos. Rompendo também com a questão do assistencialismo, da prestação de serviços e transmissão de conhecimento, concepções que predominaram por muito tempo, deixa de ser uma função isolada e fragmentada. A extensão nos anos 2000 passou a ter uma compreensão muito 
mais ampla de produção, sistematização, transmissão e resultados, no âmbito acadêmico e social:

[...] a extensão universitária como atividade acadêmica que integra o ensino e a pesquisa, viabilizando a indissociabilidade das funções da universidade, facilitando a interdisciplinaridade das atividades acadêmicas em sua totalidade. Além disto, a extensão universitária proporciona uma relação dialógica entre universidade e sociedade, através da troca de saberes entre conhecimento comum (popular) e conhecimento científico (acadêmico), materializando o confronto do conhecimento científico, tecnológico, e filosófico produzido na academia com as experiências concretas vividas na realidade social. (VILLAR, 2011, p. 22).

Outra iniciativa no sentido de institucionalizar a extensão foi o Plano Nacional de Extensão que tem como objetivo unificar nacionalmente, garantir recursos financeiros, bem como estabelecer a extensão enquanto caráter social da universidade e não apenas como sendo uma atividade acadêmica.

O Plano Nacional da Educação para o decênio 2001-2010 (PNE 2001-2010) previsto na Lei $\mathrm{n}^{\mathrm{o}}$ 10.172, aprovada em 2001, estabelece a responsabilidade das Universidades nas suas funções de Ensino, Pesquisa e Extensão na formação inicial e continuada dos profissionais da educação básica e institui que "[...] no mínimo, $10 \%$ do total de créditos exigidos para a graduação no ensino superior no país será reservado para a atuação dos estudantes em ações extensionistas.” (BRASIL, 2001, p. 36).

Embora as ideias neoliberais estejam difundidas na sociedade brasileira desde os anos 1990, atualmente, as questões de mercado aparecem com muita força na universidade e refletem diretamente na extensão universitária. A discussão atual em relação à extensão universitária se dá também em um contexto de discussão sobre a universidade. Há uma luta em relação à indissociabilidade do ensino, da pesquisa e da extensão, assim como da atuação interdisciplinar. (VILLAR, 2011).

A universidade passou a ser compreendida enquanto local de "compromisso social". O discurso é construído por meio do "diálogo" entre sociedade civil e universidade, superando a questão do assistencialismo que predominou durante a maioria do tempo, mas também o predomínio do "mercado" e a prestação de serviços. No entanto, o que se percebe na prática são ainda ações assistencialistas, e o predomínio cada vez maior das parcerias entre o público e o privado, defendidas até mesmo pelo FORPROEX.

\section{A EXTENSÃO UNIVERSITÁRIA NA UFSCAR}

A Universidade Federal de São Carlos localizada no interior do estado de São Paulo e possui quatro campi, sendo eles nas cidades de São Carlos, Araras, Sorocaba e Lagoa do Sino/Buri. O início da discussão acerca da criação de uma universidade no interior do estado de São Paulo é demarcado nos anos 1960, sua implantação foi autorizada em 1968 e suas atividades acadêmicas foram iniciadas em 1970. O processo anterior à implantação da 
Artigo

doi: $10.20396 /$ rho.v18i4.8653367

universidade foi bastante discutido, uma vez que o Brasil passava por um momento de debates que envolvia a reforma universitária.

A Universidade Federal de São Carlos surgiu no contexto do regime militar, criada em 22 de maio de 1968 a partir do Decreto 6.758. Para Sguissardi (1993), ser "fruto" de um decreto já demonstra os sinais daquele tempo e os interesses que estavam postos naquele período em não cumprir leis de maneira democrática.

Sguissardi (1993) atribui a responsabilidade da criação legal dessa universidade ao médico, pastor presbiteriano e deputado federal (UDN e ARENA), Lauro Monteiro Cruz. No processo que envolveu a "pré-história" da UFSCar, a criação legal foi um longo debate e tramitação de leis. $\mathrm{O}$ autor afirma que:

A ausência de São Carlos na tramitação da lei que autoriza a criação da UFSCar mostra que ela não foi uma reivindicação nem da população são-carlense nem de grupos organizados locais. Teria sido, de fato, obra da iniciativa pessoal de Lauro Monteiro da Cruz, articulado com o tradicional político-empresário sãocarlense Ernesto Pereira Lopes, que contou para sua rápida aprovação no Congresso Nacional, com o indispensável aval do governo Carvalho Pinto e da bancada federal paulista. (SGUISSARDI, 1993, p. 80).

A lei $\mathrm{n}^{\circ} 3.835$ de 13 de dezembro de 1960 que tratava da federalização da Universidade da Paraíba criava também a Universidade Federal de São Paulo (UFSP), sendo mencionada a proposta de criação nos artigos 11, 12 e 13. (CAMARGO, 2011). A proposta do deputado era incorporar a Escola de Engenharia de São Carlos (EESC) à UFSP, no entanto ocorreram muitas reivindicações contra essa incorporação. Um dos questionamentos acerca da legalidade da universidade foi o do jornal o Estado de São Paulo, opondo-se a uma universidade de responsabilidade da União concorrente à universidade estadual. Segundo Sguissardi (1993), sempre foi conhecida a ligação entre esse jornal e a USP.

Após oito anos, a questão da incorporação dos campis foi deixada de lado e a UFSCar se constitui a partir do decreto acima mencionado:

\footnotetext{
Esse decreto foi o resultado de quase 8 anos de articulações políticas complexas que envolveram múltiplos e variados interesses e que puseram em lados opostos, entre outros, a USP, o jornal O Estado de São Paulo, a Escola Paulista de Medicina e lideranças estaduais e nacionais da antiga UDN, nas pessoas dos deputados federais Ernesto Pereira Lopes e Lauro Monteiro da Cruz, durante todos esses anos, e do gov. Roberto de Abreu Sodré e ministros Tarso Dutra e Rondon Pacheco, nos anos 1967/68. (SGUISSARDI, 1993, p. 12-13).
}

Sguissardi (1993) traz questionamentos importantes para refletir as relações e as diferenças de interesses entre aqueles como Darci Ribeiro e Anísio Teixeira que pensaram e planejaram uma universidade, e empresários como Lauro Monteiro e Ernesto Pereira Lopes, no caso da criação da UFSCar: 
Enquanto naquela aflora e faz-se pública uma grande motivação, dentro dos ideais nacional-desenvolvimentistas, de dotar a capital da República de uma instituição do maior peso científico-acadêmico e cultural, em moldes organizativos totalmente novos e adequados aos seus grandes objetivos; nesta as motivações inicialmente desconhecidas, quando vão se tornando públicas, através das controvérsias, das ameaças de extinção ou de não implantação se revelam pouco significativas ou de natureza bastante diversa, como denunciavam seus opositores. (SGUISSARDI, 1993, p. 116).

Ou seja, o contexto em que a história acontece influencia diretamente a criação ou não de instituições. Embora os interesses dos pensadores do início da década de 1960 tivessem sido em prol do nacional-desenvolvimentismo, havia neles um objetivo de "nação", contrapondo-se aos interesses da criação da UFSCar, no qual as pessoas envolvidas buscavam satisfazer suas necessidades técnicas e pessoais. Para Sguissardi (1993), a identidade dessa universidade vai se transformar ao longo de sua história, sendo que algumas das suas características irão permanecer e outras irão se modificar.

Há pouco material disponível que trate da história da extensão na UFSCar. Ao entrar em contato com a secretaria de extensão, constatou-se que estão sendo realizados levantamentos e o escaneamento de alguns documentos para que assim se possa criar a história da PROEX.

De acordo com Almeida (2010, p. 15):

As atividades de extensão também estão presentes na história da UFSCar desde os primeiros dias, embora tenham sido poucas as diretrizes estabelecidas nesse sentido até o final da década de 1980. Com a criação das pró-reitorias, em 1989, toma corpo o processo de fortalecimento, intensificação e institucionalização das atividades de extensão, sendo implantados mecanismos organizacionais programas e núcleos de extensão.

Para Almeida (2010), os programas e núcleos de extensão abandonam a característica de prestação de serviços para uma perspectiva que irá abranger o ensino e a pesquisa na medida em que estimula as equipes multidisciplinares. A perspectiva que permeia a extensão na UFSCar é a de construção dos conhecimentos, pois o documento afirma que há um ganho:

[...] no processo de ensino e aprendizagem, tanto pela experiência adquirida pelos docentes, quanto pela oportunidade dos estudantes avaliarem na prática o que estão aprendendo e questionarem os conteúdos desenvolvidos. Ganha também a pesquisa, não só porque é através da extensão que se testa a adequação dos conhecimentos produzidos às necessidades sociais, dando sequência ao processo interminável de construção e reconstrução de conhecimento, mas também é a extensão que potencializa a identificação de temas de extensão em andamento e seis Núcleos de Extensão: UFSCar-Escola, Cidadania, Sindicato, Saúde, Município e Empreendedorismo. (ALMEIDA, 2010, p. 15).

No site da UFSCar, especificamente na página da Pró-Reitoria de Extensão, a apresentação informa que: 


\begin{abstract}
A política de extensão adotada nos últimos anos na UFSCar está comprometida com o fortalecimento da função da Universidade, isto é, produzir, sistematizar e difundir conhecimento, desenvolvendo suas atividades de pesquisa e ensino interligadas com as demandas dos setores externos (vários segmentos da população) por meio de ações de extensão. O princípio de indissociabilidade entre as atividades de ensino, pesquisa e extensão foi concretizado através dos Programas de Extensão, que estimulam e integram alunos, professores, e servidores técnico-administrativos de diferentes áreas de conhecimento no desenvolvimento de projetos institucionais multi e interdisciplinares, o que propicia uma relação mais orgânica com a sociedade e uma maior visibilidade do potencial extensionista da UFSCar. (UFSCAR, 2018).
\end{abstract}

Em 2008 foi estabelecido o Decreto No 6.495, de 30 de junho de 2008 que institui o Programa de Extensão Universitária (PROEXT), no âmbito do Ministério da Educação. Esse programa foi instituído para apoiar as instituições públicas de ensino superior no desenvolvimento dos projetos de extensão universitária com o objetivo de ampliar a interação com a sociedade.

Em 2013, o regimento das ações de extensão da UFSCar passou por um amplo debate com a comunidade acadêmica. A partir desse debate, constatou-se que o conceito de extensão universitária que está expresso na Portaria GR nº 664/99 revelou-se ainda sólido, não houve necessidade de alterá-lo. (UFSCAR, 2015). Essa portaria continuou delineando as concepções, os objetivos, os tipos de atividades de extensão, as atribuições dos órgãos acadêmicos, a organização interna da Pró-Reitoria de Extensão (ProEx) e os recursos financeiros. A política de extensão é definida pelo Conselho de Extensão (CoEx).

A concepção de extensão que permeia a extensão na UFSCar está baseada nos editais emitidos pelo Ministério da Educação (MEC). O último edital foi o PROEXT 2016- MEC/SESu, que define a extensão como:

1.2.1 Entende-se como Extensão o processo interdisciplinar, educativo, cultural, científico e político que promove a interação transformadora entre a universidade e outros setores da sociedade, mediados por alunos de graduação orientados por um ou mais professores, dentro do princípio constitucional da indissociabilidade com o Ensino e a Pesquisa.

1.2.2 Entende-se como Projeto de Extensão o conjunto de ações processuais contínuas, de caráter educativo, social, cultural ou tecnológico, com objetivo específico e prazo determinado.

1.2.3 Entende-se como Programa de Extensão o conjunto articulado de projetos e outras ações de extensão, de caráter multidisciplinar e integrado a atividades de pesquisa e de ensino. Tem caráter orgânico-institucional, integração no território e/ou grupos populacionais, clareza de diretrizes e orientação para um objetivo comum, sendo executado a médio e longo prazo por alunos orientados por um ou mais professores da instituição. (BRASIL, 2016, p. 2).

A extensão deve buscar desenvolver programas, atividades, projetos e outras ações que possuem caráter multidisciplinar e devem ser articuladas com as atividades de pesquisa e ensino para que a indissociabilidade seja de fato desenvolvida. Entre as quatro diretrizes definidas pelo edital PROEXT 2016, MEC/SESu, destacam-se duas. 
A primeira, de natureza acadêmica, deve cumprir o preceito da indissociabilidade entre ensino, pesquisa e extensão, também deve buscar interdisciplinaridade, interinstitucionalidade e interprofissionalidade; por último, deve ter impacto na formação do estudante bem como gerar produtos finais. A segunda diretriz diz respeito à relação com a sociedade e como essa deve contribuir para a superação de problemas sociais incluindo grupos excluídos; contribuir para a ampliação e disseminação dos conhecimentos; e, contribuir para a formulação, a implementação e o acompanhamento de políticas públicas. Em seguida, o documento aborda as linhas temáticas dos programas de extensão. Dentro do tema "Educação" há uma linha específica para "Educação das Relações ÉtnicosRaciais". Para esse setor as indicações são:

a) Apoio às secretarias municipais e estaduais de educação para a implementação do ensino da história e cultura da população afro-brasileira e africana, de acordo com os termos da Lei no 10.639/2003; b) Pesquisa-ação para desenvolvimento de materiais didáticos pedagógicos que contemplem e valorizem a história e a cultura africanas e afro brasileiras. c) Apoio aos Núcleos de Estudos Afrobrasileiros e Similares - NEABs para a realização de Pesquisa Ação nas áreas de: Implantação dos Centros de Fortalecimento Acadêmico para estudantes cotistas; Implementação da Lei 10.639/03 no que se refere a contribuição da educação superior para a educação básica e implementação das Diretrizes Curriculares Nacionais para a Educação das Relações Étnico-Raciais e para o ensino de História Afro-brasileira e Africana, Educação Escolar Quilombola e Educação Escolar Indígena. (BRASIL, 2016, p. 6).

\section{A EXTENSÃO UNIVERSITÁRIA SOBRE RELAÇÕES ÉTNICO- RACIAIS NA UFSCAR}

O levantamento foirealizado no site da $\mathrm{PROEXWEB}^{6}$ acerca da extensão sobre relações étnico-raciais possibilitou a construção de um quadro das atividades realizadas entre os anos de 2003 e 2011.

A seguir, é apresentada uma lista das atividades realizadas com a temática étnicoracial e posteriormente realiza-se uma breve análise sobre o caráter dessas atividades para compreender como a universidade contribui com a comunidade no sentido de combater o racismo e o preconceito e fortalecer as identidades negras. A maioria das atividades descritas a seguir foram realizadas pela Profa. Dra. Petronilha Beatriz Gonçalves e Silva e pelo Prof. Dr. Valter Roberto Silvério, ambos professores da Universidade Federal de São Carlos e integrantes do $\mathrm{NEAB}^{7}$.

Ano de 2003:

- “Gerando Cidadania - Diversidade e Etnia" - Programa Africanidades, Educação, Combate ao Racismo e a Discriminação; 
- "De preto a afro-descendente: a pesquisa sobre relações étnico-raciais no Brasil" Programa De preto a afro-descendente: a pesquisa sobre relações étnico-raciais no Brasil.

Ano de 2004:

- "Desenvolvendo e Implementando Curso sobre Cultura e História Afro-Brasileira" - Programa Africanidades, Educação, Combate ao Racismo e a Discriminação.

- II Semana da Consciência Negra da UFScar;

- Parecer CNE/CP 003/2004, Resolução CNE/CP 001/2004: estratégias para implantação e avaliação - Programa "Africanidades, Educação, Combate ao Racismo e a Discriminação".

Ano de 2005:

- Inauguração da Coleção de Thereza Santos ${ }^{8}$ e Inauguração da Coleção Ivair Augusto Alves dos Santos 9- Programa Africanidades, Educação, Combate ao Racismo e a Discriminação.

- "Avaliação de Programas de Preparação da População Negra para Ingresso e Permanência no Ensino Superior, Financiados pela Fundação Ford"- Programa "Africanidades, Educação, Combate ao Racismo e a Discriminação",

- São Paulo: Educando pela diferença para a igualdade Ciclo I - Programa "Africanidades, Educação, Combate ao Racismo e a Discriminação".

- São Paulo: Educando pela diferença para a igualdade Ciclo I - $2^{\mathrm{a}}$ fase; Programa "Africanidades, Educação, Combate ao Racismo e a Discriminação".

- São Paulo: Educando pela diferença para a igualdade Ciclo II, Ensino Médio, Programa "Africanidades, Educação, Combate ao Racismo e a Discriminação".

- São Paulo: Educando pela diferença para a igualdade Ciclo II - Ensino Médio, $2^{\mathrm{a}}$ fase, Programa "Africanidades, Educação, Combate ao Racismo e a Discriminação".

- "Mini-Curso": Uma introdução à temática étnico-racial brasileira"

Ano de 2006:

- Africanidades, aportes para Teoria da Educação" - Programa "Africanidades, Educação, Combate ao Racismo e a Discriminação".

- IV Semana da Consciência Negra 
- "Curso de Especialização Estudos Culturais Afro-Brasileiros e Africanidades, Programa "Orientação e Avaliação de Políticas Públicas para a Construção da Cidadania 2"

Ano de 2007:

- "Assessoria à Instalação e Funcionamento da Sala de Africanidades do Centro Municipal de Cultura Afro-brasileira de São Carlos" - Programa "Africanidades, Educação, Combate ao Racismo e a Discriminação".

- "Educação das relações étnico-raciais no ensino de Ciências" - Programa "Africanidades, Educação, Combate ao Racismo e a Discriminação"..

- O "Cineclube Afro-Cine" - Programa "Comunicação Audiovisual e Extensão Universitária".

- "Promovendo a Capoeira Angola num intercâmbio Universidade/Escola"

- "Apoio e acompanhamento da implantação do Programa das Ações Afirmativas da UFSCar- I"

- IV Semana Cultural Acadêmica Africana.

- "Edição da Coleção História da África", - Programa "Programa de Avaliação e Acompanhamento de Políticas para a População Negra".

- "Fórum Interinstitucional em Defesa de Ações Afirmativas no Ensino Superior" "Programa de Avaliação e Acompanhamento de Políticas para a População Negra",

- VI Semana da Consciência Negra

Ano de 2009:

- "Projeto Brasil-África: histórias cruzadas"- Programa de Avaliação e Acompanhamento de Políticas Públicas para a População Negra

- "Mapeamento dos programas de Ação Afirmativa no Ensino Superior" - Programas de Ação Afirmativa no Brasil, com o intuito de fazer uma comparação entre o Brasil e os programas existentes nos Estados Unidos.

- VII Semana da Consciência Negra

- O "Cineclube Afro-Cine" - Programa "Comunicação Audiovisual e Extensão Universitária".

Ano de 2010:

- VI Semana Acadêmica e Cultural Africana - "Programa Africanidades, Educação e Combate ao Racismo e Discriminação; 
- "Gestão e Execução de Políticas Públicas - desafios das relações étnico-raciais" Programa "Africanidades, Educação, Combate ao Racismo e a Discriminação",

- "Seminário sobre Filosofia, Pedagogia e Psicologia de Raiz Africana"

Ano de 2011:

- Avaliação de Programas de Preparação da População Negra para Ingresso e Permanência no Ensino Superior, Financiados pela Fundação Ford - Programa de Avaliação e Acompanhamento de Políticas para a população negra

- "Curso de Especialização em Educação para as Relações Étnico-Raciais" também fez parte do "Programa de Avaliação e Acompanhamento de Políticas Públicas para a População Negra".

São muitas as atividades com o objetivo de aprofundar a formação de professores para que possam trabalhar com a diversidade em suas salas. É importante que existam estas atividades, pois durante a graduação não entramos muito em contato com a educação do negro.

De acordo com Gomes (2003, p. 169):

\begin{abstract}
A formação de professores/ras, sobretudo a que visa a diversidade, deveria considerar outras questões, tais como: como os/as professores/ras se formam no cotidiano escolar? Atualmente, quais são as principais necessidades formadoras dos/das docentes? Que outros espaços formadores interferem na sua competência profissional e pedagógica? Que temas os/as professores/ras gostariam de discutir e de debater no seu percurso de formação e no dia-a-dia da sala de aula? E que temáticas sociais e culturais são omitidas, não são discutidas ou simplesmente não são consideradas importantes para a sua formação profissional e para o processo educacional dos seus alunos? Será que a questão racial está incluída nessas temáticas omitidas ou silenciadas?
\end{abstract}

As atividades de extensão da UFSCar oferecem indícios de que a universidade possibilita recursos para que haja formação inicial e continuada de professores e que esses possam entrar em contato com a temática racial que muitas vezes está omitida, tanto durante a escolarização inicial, quanto durante a formação no Ensino Superior. Ainda partindo dos argumentos de Gomes (2003), na escola além de não aprendermos sobre negros acabamos reproduzindo estereótipos e representações que aprendemos ao longo da vida, e que a escola acaba reforçando em seus livros didáticos, na prática dos seus professores, diretores e funcionários. Esses processos são delicados, e muitos profissionais não percebem, por isso, a necessidade de sensibilizar e tornar críticos os educadores para que não reproduzam a lógica racista da sociedade.

É possível perceber que as atividades de extensão da UFSCar contribuem para a demanda sobre a questão étnico-racial, em especial a formação preconizada pela lei 10.639 de janeiro de 2003, que alterou a lei 9394/96 e estabeleceu nos currículos oficiais das 
Artigo

doi: $10.20396 /$ rho.v18i4.8653367

escolas de ensino fundamental e médio, públicas e particulares, a obrigatoriedade do ensino de "[...] história e cultura afro-brasileira." (GOMES, 2003). As escolas devem incluir em seus currículos a luta dos negros no Brasil, a história da África e dos africanos, a cultura negra brasileira e a importância do negro na formação da sociedade brasileira de maneira que sejam resgatadas as suas contribuições nas áreas sociais, econômicas, políticas.

Sendo assim, essa não é uma preocupação apenas das escolas, dos governos, das políticas públicas, mas é responsabilidade também das instituições que formam os futuros professores. Gomes (2003, p. 181) faz um questionamento importante acerca dessa temática:

O que sabemos sobre história e cultura afro-brasileira? O que sabemos sobre história da África? Como não reproduzir leituras e discussões estereotipadas sobre o negro e sua cultura? Que temas deveremos privilegiar dentro do vasto campo de estudo sobre a cultura afro-brasileira? São questionamentos novos que os docentes e os cursos de formação de professores começarão a fazer.

É de extrema importância que a universidade tenha atividades de extensão que possibilitem que professores que já estão formados, e mesmo aqueles que estão no processo de formação, tenham contato com a história e cultura afro-brasileira para que assim não reproduzam as discussões estereotipadas sobre o negro e sua cultura.

Outras atividades de extensão que apareceram no levantamento foram aquelas relacionadas às Ações Afirmativas. São atividades que envolveram a avaliação da ação afirmativa nas universidades que a implementaram. É importante que essas avaliações sejam feitas pela universidade e repassadas para a comunidade como uma maneira de retornar à comunidade o que as políticas públicas estão fazendo para aqueles grupos que foram marginalizados e escravizados. É fundamental reconhecermos que se organizam e estão buscando políticas para superar as desigualdades raciais.

Muitos foram os fatores que provocaram os debates sobre a temática, bem como as discussões sobre o Brasil contemporâneo e suas relações com o passado histórico do país. É importante destacar a partir de Munanga (2009) que não podemos ignorar as reivindicações feitas no passado e no presente pelo Movimento Negro. Há muito tempo que os negros organizados buscam propostas políticas para construir a solidariedade, a identidade e a luta pelos seus direitos. Além disso, o debate sobre a miscigenação da sociedade brasileira também é antigo, e não nasce com as políticas de ações afirmativas.

Ainda de acordo com Munanga (2009), os negros são vítimas de uma discriminação que não é apenas econômica, sofrem também uma discriminação racial que é camuflada por meio da democracia racial. O Movimento Negro tem buscado conscientizar a população negra em torno de uma única identidade por meio do conceito "negro", inspirado pelo "black" norte-americano. 
Por isso, quando se fala em ações afirmativas para negros aborda-se um tema polêmico, pois muitas pessoas usam a justificativa de que o Brasil é um país miscigenado e que por conta disso existe uma dificuldade em estabelecer um critério de raça para ocupar as vagas da universidade. Assim, consideram que é uma falta de sentido que haja políticas especificas para negros. No entanto, de acordo com Silva (2009) a população é desafiada a realizar a sempre anunciada e raramente proporcionada educação para todos:

\begin{abstract}
Ações afirmativas são um conjunto de metas articuladas e complementares que integram programas governamentais, políticas de Estado, determinações institucionais, com as finalidades de: corrigir desigualdades no acesso à participação política, educação, saúde, moradia, emprego, justiça, bens culturais, reconhecer e reparar crimes de desumanização e extermínio contra grupos e populações, reconhecer e valorizar a história, cultura e identidade de grupos sociais e étnico-raciais, bem como a importância de sua participação na construção de conhecimento valioso para toda humanidade. (SILVA, 2009, p. 264).
\end{abstract}

As ações afirmativas atendem a demandas, reivindicações e propostas de grupos postos à margem pela sociedade, mormente as propostas e pressões dos movimentos sociais que por sua vez defendem a igualdade de direito, buscando a garantia e equidade nas oportunidades de realização das pessoas.

A partir do levantamento das atividades de extensão, percebe-se que há um debate sobre ações afirmativas, na UFSCar e em outras universidades do Brasil, e no âmbito da extensão isso é de fato muito importante. Para Silva (2009), é necessário que se criem maneiras de suprir as necessidades econômicas, apoiando os estudantes materialmente, financiando moradia, alimentação, saúde, incentivando inclusive a participação em atividades fora da universidade. Uma instituição que promove Ações Afirmativas, partindo da iniciativa própria ou não, é responsável por:

[...] não somente oferecer apoio à manutenção material e financeira dos contemplados mas também por sua formação acadêmica bem sucedida, assim como o é em relação a todos os seus estudantes. Dizendo de outra maneira, o insucesso de estudantes cotistas no ensino superior, se ocorrer, colocará a mostra o insucesso da própria instituição ao implantar a política. (SILVA, 2009, p. 268).

É possível perceber que a universidade se preocupa em saber como estão os estudantes que entram na universidade por meio das ações afirmativas, visto que o "fracasso" do estudante também é responsabilidade da instituição. Fazer esta afirmação não implica eximir os estudantes das responsabilidades de organização e condução de sua vida acadêmica, mas lembrar que sua formação resulta das interações com seus professores e colegas de estudo, da interpretação, utilização e realização de pesquisa e das diversificadas oportunidades educativas na área de conhecimento específico. (SILVA, 2009). As instituições de ensino superior que assumem os objetivos de garantir e divulgar os princípios da justiça e igualdade estarão com certeza atuando em busca de uma 
Artigo

doi: $10.20396 /$ rho.v18i4.8653367

sociedade reconhecidamente plural. É importante que haja estudos e atividades que comparem a implementação das ações afirmativas nas mais diversas universidades.

As atividades analisadas e as entrevistas realizadas possibilitam compreender que a UFSCar realiza contatos internacionais com países africanos e da diáspora. (GOMES, 2009). Possui também um perfil político de luta pela superação do racismo e o combate à discriminação, tem um posicionamento favorável respeito às ações afirmativas. A presença de atividades de extensão envolvendo a cultura e a história africana e afro-brasileira possibilita que a universidade se enriqueça, pois:

\begin{abstract}
Negros e indígenas, sua visão de mundo, seus conhecimentos, seus jeitos de ser e viver com base em referências não europeias, embora em desencontros e encontros com estas, são menosprezadas, a não ser quando reinterpretados nas dimensões da academia que se constrói monocultural, que se arvora a falar sobre ou em nome de negros e indígenas, mas que se sente constrangida quando eles próprios tratam dos conhecimentos que constroem, dos problemas que enfrentam, dos interesses que defendem. (SILVA, 2009, p. 271).
\end{abstract}

A participação da comunidade de uma maneira geral pode contribuir muito com a universidade, possibilitando a troca de conhecimentos, para que a instituição não continue monocultural valorizando apenas a cultura europeia. É preciso que negros e indígenas falem por si próprios, construam conhecimentos científicos valorizados pela humanidade e tenham seus conhecimentos de fato reconhecidos e também igualmente valorizados. As atividades de extensão, no sentido cultural, possibilitam que a cultura negra afro-brasileira possa chegar até a comunidade, atendendo assim a algumas das demandas do Movimento Negro.

\title{
CONSIDERAÇÕES FINAIS
}

Procurou-se neste artigo buscar uma retomada histórica da universidade e da extensão universitária no Brasil para chegar as discussões e ações da UFSCar na temática de relações étnico-raciais.

A universidade quando dialoga com a comunidade mais carente pode contribuir para a transformação da sociedade, uma vez que a instituição poderá ouvir quais são as demandas propostas pela população, assim como aprender com a comunidade externa e posteriormente socializar os conhecimentos.

Considerar a necessidade de a universidade dialogar mais com a comunidade externa não pressupõe substituir o papel do Estado, pelo contrário, o diálogo é importante inclusive para questionar o próprio Estado a fim de implementar políticas públicas que possam alcançar a população, sobretudo a mais carente. Além disso, a universidade pode também, por meio de pesquisas, desconstruir paradigmas que foram implementados ao longo da história, por meio do ensino, da pesquisa e também da extensão. 
No entanto, o que se percebe em relação à extensão universitária são os limites colocados pela própria sociedade capitalista. Não é de interesse daqueles que detêm os meios de produção que a universidade seja de fato livre, autônoma para manter uma relação de reciprocidade e de diálogo com os movimentos sociais, com a classe trabalhadora, com grupos organizados da sociedade e que tenha uma autonomia que responda aos interesses do mercado. Portanto, a universidade distancia-se daqueles com quem precisava dialogar mais e acaba mantendo relações com a iniciativa privada, ou prestando serviços para órgãos públicos. Este "papel" que a universidade cumpre, pode ser observado tanto a partir da fala dos entrevistados, quanto da revisão bibliográfica, uma vez que a instituição universitária está ligada historicamente aos interesses de uma determinada classe.

Em relação à concepção de extensão apontada pelos entrevistados, há uma percepção da necessidade de estimular para que essa função aconteça de uma maneira mais efetiva. Compreende-se que é na extensão que a universidade deveria socializar os saberes, dialogar mais com a comunidade e assim trazer aquilo que a comunidade tem de contribuição para dentro da universidade e fazer desse conhecimento o ponto de partida do próprio ensino e pesquisa.

Percebe-se a compreensão de que é a extensão o que diferencia a universidade pública, que esse é o momento em que os saberes podem confrontar-se e assim a universidade poderá comprometer-se socialmente com as camadas mais populares. Embora, considera-se que esse também deveria ser o papel do ensino e da pesquisa, uma vez que deveriam responder aos anseios da população.

Porém, os participantes da pesquisa da comunidade externa e um da comunidade acadêmica relataram a dificuldade de participar das atividades de extensão, ou até mesmo da falta de conhecimento da realização dessas atividades. As atividades que deveriam estender-se de uma maneira mais ampla para a comunidade externa acabam ficando restritas a um determinado grupo.

Um outro aspecto que apareceu em relação a extensão, foi a abertura por meio desta função para o diálogo com a comunidade, via setores industriais da iniciativa privada. A universidade acaba reafirmando o seu compromisso com a classe dominante, pois a partir de recursos públicos produz conhecimento cientifico para que a iniciativa privada possa contribuir ainda mais com a manutenção do capital.

Para ir na contramão das parcerias com a iniciativa privada, é necessário que a universidade em todas as áreas ouça mais as demandas sociais. Na área das relações étnico-raciais, na UFSCar, foi possível perceber avanços para a luta do Movimento Negro, tais como a aplicação das Diretrizes Curriculares Nacionais para a Educação das Relações Étnico-Raciais, o resgate do acervo da história da escravidão na cidade, as pesquisas sobre 
a condição do negro, e a Coleção História Geral da África, que traz novos conhecimentos sobre esse continente tão estigmatizado.

Apesar de a universidade ter limites na atuação para a transformação social, somente se ela dialogar de uma maneira livre das amarras do mercado conseguirá avanços significativos para a sociedade em geral, e em especial para a população mais pobre. No entanto, infelizmente, durante a realização desse trabalho, o Brasil estava passando por um momento político conturbado, no qual avanços que foram conseguidos por meio de políticas públicas e programas sociais depois de muita luta histórica foram freados. A política neoliberal imposta pelo governo atual tem promovido retrocesso na sociedade brasileira, ampliando as desigualdades sociais e raciais. Isto acarreta a intensificação da precarização e pode trazer prejuízos imensuráveis para as áreas sociais e, consequentemente, o povo brasileiro.

\section{REFERÊNCIAS}

ALMEIDA, N. V. F. de. et al. (Org.). Universidade Federal de São Carlos: retratos de uma trajetória 1970-2010. São Carlos: Ed. da EdUFSCar, 2010.

BUFFA, E.; PEREIRA CANALES, R. Extensão: meio de comunicação entre universidade e comunidade. Eccos Revista Científica, São Paulo, v. 9, n 1, p. 157-169, jan./jun. 2007.

BRASIL. Ministério da Educação. PROEXT: Programa de Extensão Universitária. Edital Proext 2016. Programa de Extensão Universitária MEC/SESu, 2015.

BRASIL. Lei $\mathrm{N}^{\circ}$ 10172, de 9 de janeiro de 2001. Aprova o Plano Nacional de Educação e dá outras providências. Disponível em: <http://www.planalto.gov.br/ccivil_03/leis/leis_ 2001/110172.htm>. Acesso em: 21 jan. 2018.

BRASIL. Constituição (1988). Constituição da República Federativa do Brasil. 1988. Disponível em: <www.planalto.gov.br/ccivil_03/constituicao/constituicaocompilado.htm> Acesso em: 21 jan. 2018.

CAMARGO, E. F. M. Democratizando o acesso à educação superior: o caso da UFSCAR - Campus Sorocaba. 2011. Dissertação (Mestrado em Educação) -Universidade Federal de São Carlos, Sorocaba 2011.

CUNHA, L. A. A universidade crítica. O ensino superior na república populista. 2. ed. Rio de Janeiro: Francisco Alves, 1989.

CUNHA, L. A. O Ensino Superior no Octênio FHC. Educação \& Sociedade, Campinas, v. 25, n. 55, p-14-29, abr. 2003.

FAGUNDES, J. Universidade e compromisso social: extensão, limites e perspectivas. Campinas: Ed. da UNICAMP, 1986. 
FÁVERO, M. de. L. de. A Universidade do Brasil: das origens à construção. Rio de Janeiro: Ed. da UFRJ; INEP, 2000.

FORPROEX. Conceito de extensão, institucionalização e financiamento. ENCONTRO NACIONAL DE PRÓ-REITORES DE EXTENSÃO DAS UNIVERSIDADES PÚBLICAS BRASILEIRAS, 1., 1987, Brasília. Anais... Brasília: UNB, 04 e 05 de novembro de 1987. Disponível em: <https://www.ufmg.br/proex/renex/images/ documentos/1987-I-Encontro-Nacional-do-FORPROEX.pdf >. Acesso em: 21 jan. 2018

GOMES, N. L. Educação, identidade negra e formação de professores/as: um olhar sobre o corpo negro e o cabelo crespo. Educação e Pesquisa, São Paulo, v. 29, jun. 2003.

GOMES, N. L. Para além das bolsas acadêmicas: ações afirmativas e o desafio da permanência dos (as) jovens negros (as) na universidade pública. In: SILVÉRIO, V. R. (Org.) Ações Afirmativas nas políticas educacionais: o contexto pós-Durban. São Carlos: EdUFSCar, 2009. p. 197-213.

LEHER, R. Movimentos sociais, padrão de acumulação e crise da universidade. In: REUNIÃO NACIONAL DA ANPED, 37., 2015, Florianópolis. Anais... Florianópolis: Associação Nacional de Pós-graduação e Pesquisa em Educação, 2015. Disponível em: <http://www.anped.org.br/sites/default/files/trabalho-de-roberto-leher-para-o-gt11.pdf>. Acesso em: 21 jan. 2018.

MICHELOTTO, R. M. A liberação do acesso e a extensão como estratégias dedemocratização da universidade: a experiência da Itália e do Brasil. 1999. Tese (Doutorado) - Universidade Federal de São Carlos, São Paulo, 1999.

MENEGHEL, S. M. A crise da universidade moderna no Brasil. 2001. Tese (Doutorado) Universidade Estadual de Campinas, Campinas, SP, 2001. Disponível em:

<http://www.repositorio.unicamp.br/handle/REPOSIP/252072>. Acesso em: 21 jan. 2018.

MUNANGA, K. Fundamentos antropológicos e histórico-juridicos das políticas de universalização e de diversidade nos sistemas educacionais no mundo contemporâneo. In: SILVÉRIO, V. R. (Org.) Ações Afirmativas nas políticas educacionais: o contexto pósDurban. São Carlos: EdUFSCar, 2009. p. 171-195.

SANCHEZ, L. H.T. A extensão universitária: o histórico da experiência da UNICAMP. Dissertação (Mestrado em Educação) - Universidade Estadual de Campinas, Campinas, 1996.

SANFELICE, J. L. Movimento estudantil: a UNE na resistência ao golpe de 1964. Campinas. SP: Alínea, 2008.

SANTO, É. F. O ensino superior no Brasil e os acordos MEC-USAID: o intervencionismo norte-americano na educação brasileira. 2005. Dissertação (Mestrado em Educação) - Universidade Estadual de Maringá, Maringá, 2005. 
Artigo

doi: $10.20396 /$ rho.v18i4.8653367

SAVIANI, D. Extensão universitária: uma abordagem não extensionista. Educação e Sociedade, São Paulo, n. 8, p. 61-73, mar. 1981.

SEMERARO, G. Da sociedade de massa à sociedade civil: a concepção da subjetividade em Gramsci. Educ. Soc., Campinas, v. 20, n. 66, p. 65-83, Apr. 1999. Disponível em: $<$ http://www.scielo.br/scielo.php?script=sci_arttext\&pid=S0101-73301999000100004 \&lng=en\&nrm=iso>. Acesso em: 21 jan. 2018.

SILVA, P, B, G. Ações afirmativas para além das cotas. In: SILVÉRIO, V. R. (Org.) Ações Afirmativas nas políticas educacionais: o contexto pós-Durban. São Carlos: EdUFSCar, 2009.

SGUISSARDI, V. Universidade, fundação e autoritarismo: o caso da UFSCar. São Paulo: Estação Liberdade; São Carlos: Universidade Federal de São Carlos, 1993.

SGUISSARDI, V. Reforma universitária no Brasil - 1995-2006: precária trajetória e incerto futuro. Educ. Soc., Campinas, v. 27, n. 96 - Especial, p. 1021-1056, out. 2006.

SOUSA, A. L. L. A História da Extensão Universitária. Campinas: Alínea, 2000.

SOUZA, D. F. de. Movimento Negro de São Carlos e a UFSCAR: a extensão universitária sobre relações étnico-raciais. Dissertação (Mestrado) - Universidade Federal de São Carlos, São Carlos, 2017.

TEIXEIRA, A. Educação para a democracia: introdução à administração educacional. Rio de Janeiro: Ed. da UFRJ, 1997.

TEIXEIRA, A. Ensino Superior no Brasil: análise e interpretação de sua evolução até 1969. Rio de Janeiro: Editora da Fundação Getúlio Vargas, 1989.

UFSCAR. Universidade Federal de São Carlos. Plano de Cultura UFSCar (2015 -2017): Integração pela Extensão Universitária. São Carlos, 2015.

UFSCAR. Universidade Federal de São Carlos. Pró-Reitoria de Extensão (ProEx). Disponível em: <http://www.proex.ufscar.br/sobre>. Acesso em: 21 jan. 2018.

VILLAR, A. E. de. V. Extensão Universitária: concepções e ações na UFRN, sob a temática direitos humanos e justiça no período de 2008 a 2010. 2011. Dissertação (Mestrado) - Universidade Federal do Rio Grande do Norte, Natal, 2011.

ZILLER, J. et al. A Extensão como forma de conectar saberes. In: MAYORGA, C. (Org.) Universidade cindida, universidade em conexão: ensaios sobre democratização da universidade. Belo Horizonte: Ed. da UFMG, 2010. p. 234-247.

Notas: 


\section{Revista HIIS'TNIDIBR On-lime}

${ }^{1}$ Mestre pelo Programa de Pós Graduação em Educação da Universidade Federal de São Carlos (UFSCar). Graduada no curso de Pedagogia na UFSCar. Professora nos anos iniciais do Ensino Fundamental na rede estadual de São Carlos-SP.

${ }^{2}$ Doutor em Educação pela UNICAMP/FE. Professor do Departamento de Educação (Ded) e do Programa de Pós-Graduação em Educação da UFSCar (São Carlos).

${ }^{3}$ Para Gramsci, a sociedade civil é, antes de tudo, o extenso e complexo espaço público não estatal onde se estabelecem as iniciativas dos sujeitos modernos que com sua cultura, com seus valores ético-políticos e suas dinâmicas associativas chegam a formar as variáveis das identidades coletivas. É lugar, portanto, de grande importância política onde as classes subalternas são chamadas a desenvolver suas convicções e a lutar para um novo projeto hegemônico enraizado na gestão democrática e popular do poder. (SEMERARO,1999, p. 70)

${ }^{4} \mathrm{O}$ Movimento Estudantil não tinha concepções hegemônicas, os integrantes eram muito divergentes entre si. Foi criado em 1961. (CUNHA, 1989).

5 Os chamados "Acordos MEC/USAID" foram firmados entre o governo brasileiro e o governo norteamericano, através da USAID. Segundo as diretrizes da Aliança Para o Progresso, esses acordos eram voltados para a cooperação entre os dois países, visando à "modernização" do sistema educacional do Brasil. Todavia, tudo indica que tais acordos compuseram o bloco histórico resultante do padrão de acumulação capitalista posto em prática pelo governo militar, baseado na aplicação de medidas que ampliavam a presença do capital norte-americano e europeu em nosso país. Basta observar que a Reforma Universitária de 1968 fez parte dos planos de desenvolvimento engendrados pela Aliança Para o Progresso, no qual o modelo norteamericano de universidade faria parte do processo de ajuda mútua estabelecida pela Carta de Puntadel Este. Além disso, a reforma desenvolveu-se em estreita relação com a necessidade que o regime teve de conquistar o apoio das camadas médias para o projeto econômico posto em prática. Assim, com o acesso ao ensino superior ampliado, as camadas médias acreditavam que estavam garantidas a ascensão e manutenção social. Ou seja, através das medidas econômicas do chamado "milagre econômico" o governo militar proporcionou a essa fração da classe trabalhadora o aumento do consumo dos bens materiais e intelectuais, esses últimos presentes nas reformas do ensino. (SANTO, 2005, p. 105).

${ }^{6}$ As informações citadas estão disponíveis no site: http://www.proexweb.ufscar.br/principal.html

${ }^{7}$ O Núcleo de Estudos Afro-brasileiros da Universidade Federal de São Carlos NEAB/UFSCar foi criado em 1991, por iniciativa de professores, estudantes, servidores e de ativistas do Movimento Negro da cidade de São Carlos/SP. O NEAB tem desenvolvido desde sua criação atividades de ensino, pesquisa e extensão. O grupo atua em diferentes áreas e os objetivos são: realização de estudos para subsidiar a formulação e a execução de políticas públicas de promoção da igualdade racial; estudar e divulgar a realidade dos afrodescendentes na sociedade brasileira, com vistas a criar mecanismos de combate ao racismo e às discriminações; registrar a memória social afro-brasileira; capacitar educadores em geral para que promovam atitudes de respeito às culturas; capacitar educadores em geral para que promovam atitudes de respeito às culturas dos grupos étnico-raciais e sociais presentes na escola e organizem programas e materiais de ensino que visem ao diálogo entre as culturas. Fonte: http://www.neab.ufscar.br/.

${ }^{8}$ A Coleção Thereza Santos reúne o acervo da teatróloga, publicitária, atriz e pesquisadora que dá nome ao acervo. Thereza é também militante do movimento negro e ex-assessora de cultura afro-brasileira da Secretaria de Estado da Cultura de São Paulo. Fonte: http://www.neab.ufscar.br/biblioteca-digital/

${ }^{9}$ A Coleção Ivair Alves dos Santos, pesquisador e doador do material, é composta por um acervo que possui 778 documentos catalogados até o momento. É composto por materiais sobre a história do Movimento Negro no Brasil, em jornais de circulação nacional e internacional, revistas, artigos científicos, folders e cartazes de seminários e eventos ligados ao Conselho de Participação e Desenvolvimento da Comunidade Negra do Estado de São Paulo. A coleção está sob os cuidados da Unidade Especial de Informação e Memória (UEIM) do Centro de Educação e Ciências Humanas $(\mathrm{CECH})$ da UFSCar. Fonte: http://www.neab.ufscar.br/biblioteca-digital/.

Submetido em: 06/09/2018

Aprovado em: 11/12/2018

Publicado em: 17/12/2018

Rev. HISTEDBR On-line, Campinas, v.18, n.4 [78], p.1016-1045, out./dez. 2018 